\title{
PERTUMBUHAN AWAL TITI (Gmelina moluccana)
}

\section{EARLY GROWTH OF TITI (Gmelina moluccana)}

Oleh:

\author{
Febian F. Tetelay ${ }^{1}$, Lily Pelupessy ${ }^{2}$, Yacob Rahayaan ${ }^{3}$, Bronie S. Serlaloy ${ }^{4}$, Hein A. Nimreskossu ${ }^{5}$, \\ Rizaldy R. Tuharea ${ }^{6}$ \\ ${ }^{1,2}$ Dosen Dosen Jurusan Kehutanan Faperta Unpatti \\ ${ }^{3,4,5,6}$ Mahasiswa Jurusan Kehutanan Faperta Unpatti \\ Email: febiantetelay @gmail.com \\ \begin{tabular}{|l|l} 
Diterima:21 Maret 2020 & Disetujui: 11 April 2020
\end{tabular}
}

\begin{abstract}
Abstrak
Titi atau Gmelina moluccana merupakan salah satu jenis dari Famili Lamiaceae yang tumbuh di Maluku. Jenis ini walaupun merupakan jenis asli setempaat tetapi masih sangat kurang informasi tentang pertumbuhannya. Penelitian ini bertujuan untuk mengetahui pertumbuhan jenis ini sejak ditanam di lapangan hingga pada tahun keenam, factor-faktor lingkungan yang mempengaruhi pertumbuhannya. Data yang dikumpul berupa tinngi dan diameter tanaman, suhu udara, kelembaban udara, $\mathrm{pH}$ tanah, kelembaban tanah, intensitas cahaya matahari. Faktor-faktor lingkungan tersebut kemudian dihubungkan dengan tinggi dan diameter tanaman untuk mengetahui factor lingkungan yang mempengaruhi pertumbuhan tanamaan ini melalui persamaan regresi linier berganda. Selain itu juga dihitung riap ratarata tahunan dan riap tahun berjalan untuk mengetahui daur dari tanaman ini. Berdasarkan hasil penelitian tanaman Titi sampai pada tahun keenam memliki rata-rata riap tahunan dan riap tahun berjalan adalah 0,99 meter/tahun dan 1,46 meter untuk tinggi serta $1,62 \mathrm{~cm} /$ tahun dan 2,50 cm untuk diameter. Sampai tahun keenam jenis ini belum memasuki daur tekniknya, sedangkan untuk keperluan kayu pertukangan maka jenis ini dapat dipanen pada umur 24,5 tahun. Faktor lingkungan yang berpengaruh terhadap pertumbuhan Titi adalah $\mathrm{pH}$ tanah dan kelemaban tanah.
\end{abstract}

Kata Kunci : Titi, pertumbuhan, riap, daur

\begin{abstract}
Titi or Gmelina moluccana is a type of the Lamiaceae family that grows in Maluku. Although this species is local, there is still very little information about its growth. This study aims to determine the growth of this species from planting in the field until the sixth year, environmental factors that affect its growth. Data collected in the form of plant height and diameter, air temperature, humidity, soil $\mathrm{pH}$, soil moisture, sunlight intensity. Environmental factors are then related to plant height and diameter to determine environmental factors that affect the growth of these plants through multiple linear regression equations. Besides, the mean annual increment and the current annual increment is also calculated to determine the cycle of this plant. Based on the results of research, Titi plants up to the sixth year have an men annual increment and the current annual increment is 0.99 meters/year and 1.46 meters for height and 1.62 $\mathrm{cm} /$ year and $2.50 \mathrm{~cm}$ for diameter. Until the sixth year this species has not entered the techniquecycle, while for woodworking purposes, this species can be harvested at the age of 24.5 years. Environmental factors that affect the growth of Titi are soil $\mathrm{pH}$ and soil moisture
\end{abstract}

Keywords : Titi, growth, increment, cycle

DOI: $10.30598 /$ jhppk.2020.4.2.122

ISSN ONLINE: 2621-8798

Page 122 


\section{PENDAHULUAN}

Hutan merupakan habitat dari berbagai jenis tumbuhan, mulai dari tumbuhan yang sederhana sampai dengan tumbuhan tingkat tinggi. Hutan di Indonesia merupakan salah satu hutan di dunia yang memiliki beranekaragam jenis tumbuhan, dan pohon-pohon merupakan tumbuhan tingkat tinggi yang mendominasi hutan di Indonesia. Gmelina moluccana merupakan salah satu di antara sekian banyak jenis tumbuhan yang tumbuh dengan subur di hutan Indonesia. Jenis in merupakan jenis yang dapat di jumpai pada daerah bagian Timur Indonesia, terutama di kepulauan Maluku, dan jenis ini merupakan jenis asli di daerah ini. Jenis ini merupakan jenis endemik Maluku. Jenis ini tumbuh pada daerah persebaran alaminya dari hutan alam primer maupun sekunder. Tumbuh pada ketinggian tempat 0-800 $\mathrm{m} \mathrm{dpl,} \mathrm{pada} \mathrm{tanah} \mathrm{dengan} \mathrm{tekstur}$ liat atau lempung berpasir, kadang-kadang pada batu kapur. Jenis ini berbunga pada bulan Januari sampai Oktober dan berbuah pada bulan Maret sampai Desember (de Kok, 2012). Masyarakat setempat mengenal jenis ini dengan nama Titi atau Jati Maluku karena pohon dari jenis ini mirip dengan pohon jati.

Seperti halnya jati, jenis ini juga termasuk dalam famili Laminaceae. Sebelumnya bersama dengan jati jenis ini masuk dalam famili Verbenaceae. Berbeda dengan jenis yang memiliki genus yang sama yaitu Gmelina arborea, jenis ini kurang banyak dikenali. Bahkan data tentang jenis ini

\section{METODE PENELITIAN}

Penelitian ini berlangsung pada Demplot Sumber Benih di Desa Hatusua, Kecamatan Kairatu, Kabupaten Seram Bagian Barat. Penelitian ini berlansung selama 6, 5 tahun. masih sangat sedikit. Informasi tentang pertumbuan jenis ini masih sangat terbatas dibandingkan dengan jenis lain yang masuk famili Laminaceae di Indonesia. Pertumbuhan dapat diartikan sebagai pertambahan dimenis pohon baik tinggi maupun diameter (Paembonan,2014). Jenis pohon yang tumbuh di hutan memliki karakteristik pertumbuhan tertentu yang dipengaruhi oleh factor genetic dan factor lingkungan (Daniel et al, 1979, dalam Paembonan, 2014). Selanjutnya menurut Paembonan (2014), klasifikasi pertumbuhan pohon dalam suatu tegakan atau kawasan hutan sangat berguna untuk keperluan perencanaan pengelolaan hutan, khususnya untuk pengelolaan hutan yang berkelanjutan.

Pengetahuan tentang pertumbuhan Gmelina moluccana sangat penting, karena informasi yang diberikan menjadi dasar bagi pemberian perlakuan silvikultur bagi jenis tersebut. Hal ini juga sangat berhubungan dengan pengembangan jenis ini pada masa yang akan datang. Dengan demikian maka penelitian tentang pertumbuhan dari jenis Gmelina moluccana sangat penting untuk dilakukan karena dapat memberikan informasi tentang pertumbuhan jenis ini terutama pertumbuhan awalnya.. Dengan demikian maka tujuan dari penelitian ini yaitu untuk : mengetahui pertumbuhan awal jenis ini mulai dari penanaman sampai pada umur 6 tahun dan mengetahui factor-faktor lingkungan apa saja yang mempengaruhi pertumbuhan dari jenis ini.

Penelitian dilaksanakan sejak bulan Januari tahun 2013 hingga pada bulan Juli tahun 2019.

Peralatan yang dipergunakan dalam penelitian ini meliputi :Kaliper, Mistar Ukur, Haga Meter, Galah, Meter Kain phiband, Termometer 
Bola Basah Dan Bola Kering, Luxmeter, Soil Te ster. Bahan yang digunakan adalah Tanaman Titi yang terdapat pada Demplot Sumber Benih di Desa Hatusua. Sedangkan Data Sekunder yang diambil adalah curah hujan dari Stasiun BMKG Kairatu dan jenis tanah berdasarkan Peta Sumberdaya Tanah.

Penelitian ini dimulai dengan proses penyiapan lokasi penanaman (blok tanaman) Titi sejak Januari 2013 diikuti dengan penanaman tanaman pada Akhir bulan Juni 2013. Tanaman ini di tanam dilapangan dengan jarak tanam 3 meter $x$ 3 meter. Tanaman sampel yang dipilih berjumlah 75 anakan dengan pertimbangan tanaman yang diambil tidak terkena efek tepi (edge effect) dan tanaman juga tidak akan hilang akibat penjarangan yang dilakukan. Pengukuran awal dilakukan sejak tanaman berumur dua minggu di lapangan (pertengahan Juli 2013). Pengukuran dilakukan dua kali satahun yaitu pada bulan Januari dan bulan Juli. Adapun parameter yang diukur yaitu tinggi tanaman dan diameter tanaman.

Faktor-faktor yang mempengaruhi pertumbuhan tanaman titi dianalisis dengan menggunakan analisis regresi linier berganda dengan metode step wise, artinya hanya factor-faktor yang mempengaruhi pertumbuhanlah yang akan menyusun persamaan regresi linier tersebut. $\mathrm{Y}=$ parameter pertumbuhan tanaman Titi (tinggi atau diameter) $\mathrm{b}_{0}, \mathrm{~b}_{1} \ldots \mathrm{b}_{\mathrm{n}}=$ kostanta regresi

$\mathrm{X}_{1} \ldots . \mathrm{X}_{\mathrm{n}}=$ factor-faktor lingkungan yang mempengaruhi pertumbuhan Titi

Riap Tanaman Titi yang dihitung berdasarkan perhitungan adalah Riap Tahun berjalan dan Riap Rata-Rata Tahunan.

Riap Tahun berjalan dihitung dengan menggunakan rumus :

$$
\begin{aligned}
\text { Riap Tinggi }= & \frac{H n+1-H n}{T n+1-T n}=\frac{\Delta H}{\Delta T} \\
\text { Riap Diameter } & =\frac{D n+1-D n}{T n+1-T n}=\frac{\Delta D}{\Delta T} \\
\text { Riap tinggi } & =\frac{T(m)}{\operatorname{Umur}(\text { tahun })}
\end{aligned}
$$

Data factor-faktor yang mempengaruhi pertumbuhan dari tanaman titi meliputi suhu, kelembaban udara, $\mathrm{pH}$ tanah, kelembaban tanah serta intensitas cahaya yang diterima dilakukan besamaan dengan pengukuran tinggi dan diameter. Terkecuali intensitas cahaya yang baru diambil datanya pada tahun keempat, semua factor lingkungan yang lain juga diukur bersamaan dengan pengukuran tinggi dan diameter tanaman. Data curah hujan sendiri merupakan data sekunder yang diperoleh dari Stasiun BMKG Kecamatan Kairatu, Kabupaten Seram Bagian Barat. Data tinggi dan diameter yang diukur selanjutnya untuk menentukan fase pertumbuhan maupun riap dari tanaman titi. Sedangkan untuk mengetahui factorfaktor yang mempengaruhi pertumbuhan jenis ini menggunakan analisis regresi linier berganda. Analisis Data Untuk mengetahui pertumbuhan tanaman Titi di lapangan maka dilakukan pengukuran tinggi dan diameter yang dilakukan setiap tahun. Pengukuran dilakukan dengan alat ukur yang sesuai dengan tingkatan pertumbuhan dari tanaman tersebut.

Persamaan regresi linier berganda yang menyatakan hubungan antara factor lingkungan dengan pertumbuhan tanaman titi sebagai berikut

$$
\mathrm{Y}=\mathrm{b}_{0}+\mathrm{b}_{1} \mathrm{X}_{1}+\ldots+\mathrm{b}_{\mathrm{n}} \mathrm{X}_{\mathrm{n}}
$$

Di mana :

Dimana :

$\mathrm{Hn}+1$ = tinggi tahun sekarang (m)

$\mathrm{Hn}=$ tinggi tahun kemarin $(\mathrm{m})$

Dn $+1=$ Diameter tahun sekarang $(\mathrm{cm})$

Dn = Diameter tahun lalu $(\mathrm{cm})$

$\mathrm{Tn}+1=$ tahun pengukuran sekarang

$\mathrm{Tn} \quad=$ tahun pengukuran kemarin

Riap Rata-rata Tahunan dihitung dengan menggunakan rumus : 

Dimana :

$$
\text { Riap diameter }=\frac{D(\mathrm{~cm})}{\operatorname{Umur}(\text { tahun })}
$$

D : Diameter $(\mathrm{cm})$

T:Tinggi $(m)$

\section{HASIL DAN PEMBAHASAN}

Pertumbuhan Tanaman Titi (Gmelina moluccana)

Pertumbuhan tanaman Titi diketahui berdasarkan pengukuran diameter dan tinggi tanaman. Rata-Rata diameter dan tinggi tanaman Titi selama 6 tahun pengamatan disajikan pada tabel 1 di bawah ini :

Tabel 1. Rata-Rata Diameter dan Tinggi Tanaman Titi (Gmelina moluccana)

\begin{tabular}{ccccccc}
\hline & \multicolumn{3}{c}{ Diameter $(\mathrm{cm})$} & \multicolumn{3}{c}{ Tinggi $(\mathrm{m})$} \\
\hline Tahun & Maksimum & Minimum & $\begin{array}{c}\text { Rata- } \\
\text { rata }\end{array}$ & Maksimum & Minimum & $\begin{array}{c}\text { Rata- } \\
\text { Rata }\end{array}$ \\
\hline 0 & 0.78 & 0.1 & 0.54 & 0.71 & 0.3 & 0.53 \\
1 & 1.3 & 0.56 & 0.94 & 1.12 & 0.54 & 0.78 \\
2 & 2.68 & 1.37 & 1.89 & 1.89 & 0.96 & 1.34 \\
3 & 4.97 & 2.42 & 3.47 & 3.16 & 1.48 & 2.24 \\
4 & 10.56 & 4.96 & 6.94 & 4.95 & 3.09 & 3.88 \\
5 & 19.5 & 7.6 & 11.87 & 8.5 & 4.5 & 6.45 \\
6 & 25 & 9.2 & 15.55 & 12.5 & 6 & 9.03 \\
\hline
\end{tabular}

Sumber : data pengukuran 2013-2019

Berdasarkan tabel di atas maka terlihat baik diameter maupun tinggi tanaman Titi terus mengalami pertambahan dari tahun ke tahun dan bila digambarkan dalam grafik maka terlihat bahwa pada tahun pertama sampai tahun ketiga tanaman titi masih ada dalam fase pertumbuhan lambat (lag fase) sedangkan tahun keempat sudah memasuki fase pertumbuhan cepat (log fase) seperti terlihat pada gambar 1 dan 2 di bawah ini :

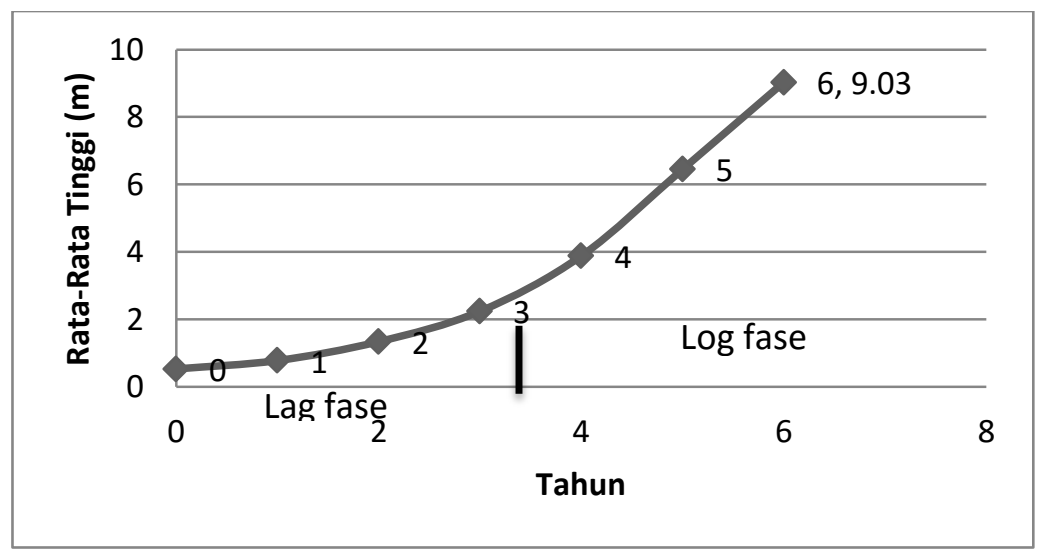

Gambar 1. Rata-Rata Pertambahan Tinggi Tanaman Titi 
Pertumbuhan tanaman Titi berdasarkan gambar 1 terlihat mulai membentuk kurva eksponensial dimana kurva eksponensial merupakan kurva yang menggambarkan pertumbuhan pohon secara normal. Lag fase atau fase pertumbuhan lambat pada awal pertumbuhan tanaman ini berakhir pada tahun ketiga dan selanjutnya telah memasuki log fase atau fase pertumbuhan cepat

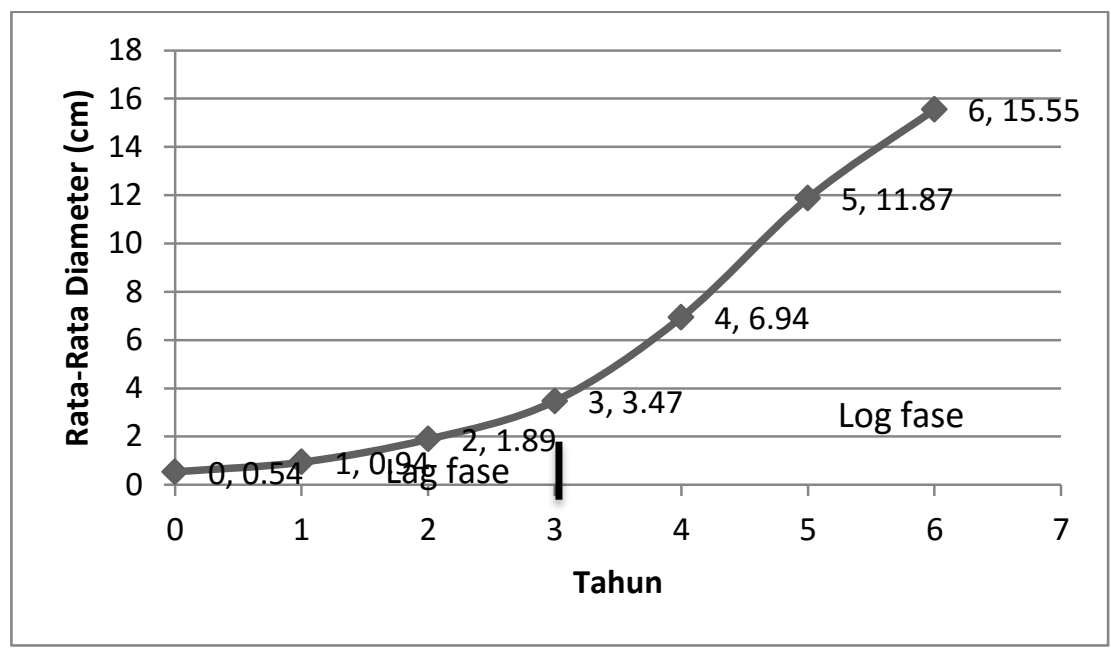

Gambar 2. Rata-Rata Pertumbuhan Diameter Tanaman Titi

Seperti halnya pada pertumbuhan tinggi, pertumbuhan diameter dari tanaman Titi juga mulai menunjukkan kurva eksponensial seperti pada gambar 2 di atas. Lag fase pada awal pertumbuhan juga berakhir pada tahun ketiga dan selanjutnya memasuki log fase. Menurut Paembonan (2014) lag fase terjadi pada tanaman ketika berada pada tingkatan semai sampai sapihan, sedangkan log fase terjadi pada akhir tingkat sapihan.

\section{Faktor-Faktor Lingkungan yang Mempengaruhi Pertumbuhan Titi}

Berdasarkan tabel 1, maka factor-faktor lingkungan yang diamati meliputi suhu udara,curah hujan, kelembaban udara, $\mathrm{pH}$ tanah dan kelembaban tanah. Faktor-faktor lingkungan ini kemudian dihubungkan dengan tinggi dan diameter tanaman dalam analisis regresi beganda. 1. Tinggi Tanaman Titi

Faktor lingkungan yang mempengaruhi pertumbuhan tinggi tanaman titi berdasarkan analisis regresi berganda adalah factor $\mathrm{pH}$ tanam dan kelembaban tanah. Persamaan yang dihasilkan sebagai berikut :

$\mathrm{Y}=-23.88+3.073 \mathrm{X}_{1}+0.3252 \mathrm{X}_{2}$

Di mana : $\mathrm{Y}=$ tinggi tanaman titi ( meter)

$$
\mathrm{X}_{1}=\mathrm{pH} \text { tanah }
$$$$
\mathrm{X}_{2}=\text { kelembaban tanah. }
$$

PH tanah berhubungan dengan ketersediaan nutrisi dalam tanah. Pada Tabel 1 terlihat bahwa sejak tanaman ini di tanam maka $\mathrm{pH}$ tanahnya mengalami peningkatan dari tahun ke tahun dari $\mathrm{pH}$ tanam masam ke $\mathrm{pH}$ tanah agak 
masam. Semakin medekati $\mathrm{pH}$ netral mengidikasikan ketersediaan hara bagi tanaman yang semakin baik.

Kelembaban tanah berkaitan erat dengan ketersediaan air di dalam tanah. Air sangat diperlukan oleh tanaman dalam proses

\section{Diameter Tanaman Titi}

Berdasarkan analisis regresi berganda

yang dilakukan maka diperoleh hubungan antara diameter tanaman Titi dengan fektor-faktor lingkungan sebagai berikut :

Sama halnya dengan pertumbuhan tinggi, pertumbuhan diameter dari tanaman titi juga dipengaruhi oleh $\mathrm{pH}$ tanah dan kelembaban tanah. Artinya ketersediaan unsur hara dan air sangat penting pada pertumbuhan awal dari tanaman ini. $\mathrm{pH}$ tanah dan kelembaban tanah pertumbuhannya. Terlihat jelas pada tabel 1 kelembaban tanah mengalami peningkatan dari tahu ke tahun artinya selain faktor ini berpengaruh bagi tanaman titi, tetapi sebaliknya kehadiran tanaman titi menyebabkan meningkatnya ketersediaan air pada tanah.

$Y=-45.78+6.10 X_{1}+0.5690 X_{2}$

Di mana : $\mathrm{Y}=$ diameter tanaman titi $(\mathrm{cm})$

$$
\begin{aligned}
& \mathrm{X}_{1}=\mathrm{pH} \text { tanah } \\
& \mathrm{X}_{2}=\text { kelembaban tanah. }
\end{aligned}
$$

merupakan dua dari tiga faktor yang mempengaruhi proses dekomposisi bahan organik (El-Naby, tahun 2020 dalam Karamina dkk, tahun 2017) 
Riap Tanaman Titi

1. Riap Tinggi Tanaman Titi (G. moluccana)
Pengukuran terhadap tinggi tanaman sampai dengan riap tanaman dapat dilihat pada tabel 2 berikut ini :

Tabel 2. Rata-Rata Tinggi, Riap Rata-Rata Tahunan Dan Riap Tahun Berjalan Tinggi Tanaman Titi

\begin{tabular}{cccc}
\hline Tahun & Rata-Rata Tinggi $(\mathrm{m})$ & $\begin{array}{c}\text { Riap Rata-Rata Tahunan } \\
(\mathrm{m})\end{array}$ & $\begin{array}{c}\text { Riap Tahun } \\
\text { Berjalan }(\mathrm{m})\end{array}$ \\
\hline 0 & 0.53 & 0.00 & 0.00 \\
1 & 0.78 & 0.78 & 0.25 \\
2 & 1.34 & 0.67 & 0.81 \\
3 & 2.24 & 0.75 & 0.90 \\
4 & 3.88 & 0.97 & 1.64 \\
5 & 6.45 & 1.29 & 2.57 \\
6 & 9.03 & 1.51 & 2.58 \\
\hline Rata-Rata & & 0.99 & 1.46 \\
\hline
\end{tabular}

Sumber: Hasil Penelitian Tahun 2013-2019

Berdasarkan tabel di atas dapat dilihat bahwa tinggi tanaman titi terus mengalami pertambahan dari tahun pertama penanaman sampai pada tahun keenam. Begitu juga dengan riap tahun berjalan, sedangkan riap-rata-rata tahunan mengalami penurunan pada tahun kedua tetapi seterusnya mengalami peningkatan.

Rata-rata pertambahan tinggi tanaman titi selama enam tahun mencapai 0,99 meter.
Pertumbuhan tinggi memang lebih kecil dibandingkan dengan pertumbuhan diameter yaitu $15,59 \%$ sedangkan untuk diameter $29,25 \%$. Hal ini bersesuaian juga dengan penelitian yang dilakukan oleh Sofyan dkk (2013) karena riap tinggi pada awal pertumbuhan dipengaruhi juga oleh perlakuan silvikultur yang diberikan seperti pemangkasan. Pertumbuhan tinggi jenis ini dapat dilihat pada gambar 3 :

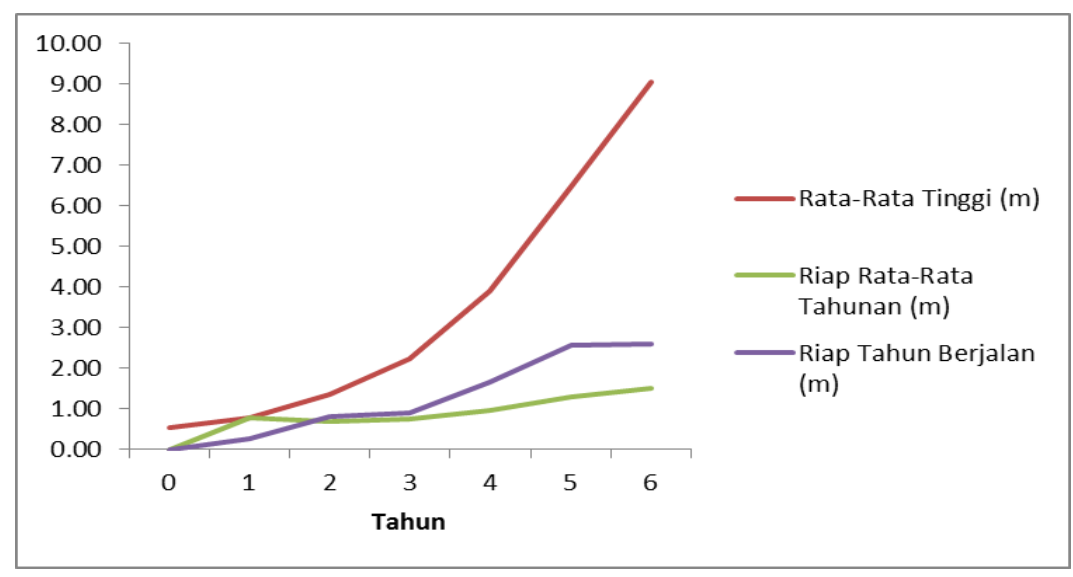

Gambar 3. Rata-Rata, Riap Rata-Rata Tahunan Dan Riap Tahun Berjalan Tinggi Tanaman Titi 


\section{Riap Diameter Tanaman Titi}

Pengukuran terhadap diameter tanaman

titi selama 6 tahun dan riap rata-rata tahunan serta riap tahun berjalan dapat dilihat pada tabel 3 berikut ini ;

Tabel 3. Rata-Rata Diameter, Riap Rata-Rata Tahunan Dan Riap Tahun Berjalan Diameter Tanaman Titi

\begin{tabular}{cccc}
\hline Tahun & $\begin{array}{c}\text { Rata-Rata } \\
\text { Diameter }(\mathrm{cm})\end{array}$ & $\begin{array}{c}\text { Riap Rata-Rata Tahunan } \\
(\mathrm{cm})\end{array}$ & $\begin{array}{c}\text { Riap Tahun Berjalan } \\
(\mathrm{cm})\end{array}$ \\
\hline 0 & 0.54 & 0.00 & 0.00 \\
1 & 0.94 & 0.94 & 0.40 \\
2 & 1.89 & 0.95 & 0.95 \\
3 & 3.47 & 1.16 & 1.58 \\
4 & 6.94 & 1.74 & 3.47 \\
5 & 11.87 & 2.37 & 4.93 \\
6 & 15.55 & 2.59 & 3.68 \\
\hline Rata-Rata & & 1.62 & 2.50 \\
\hline
\end{tabular}

Sumber : Hasil Penelitian Tahun 2013-2018

Berdasarkan tabel di atas maka dapat terlihat bahwa rata-rata diameter tanaman titi terus mengalami peningkatan begitu juga dengan riap rata-rata tahunan, tetapi untuk riap tahun berjalan mengalami penurunan pada tahun ke-6. Berdasarkan riap rata-rata tahunan yang dihitung maka riap diameter tanaman titi pada demplot sumber benih Desa Hatusua mencapai 1,62 cm per tahun. Pertambahan riap ini lebih besar dibandingkan dengan pertambahan riap diameter pohon pada hutan alam yang mencapai $1 \mathrm{~cm} /$ tahun (Anonim, 1976) dalam Abdulrahman dkk (2009).Pertumbuhan diameter tanaman ini dapat dilihat pada gambar 4 berikut ini :

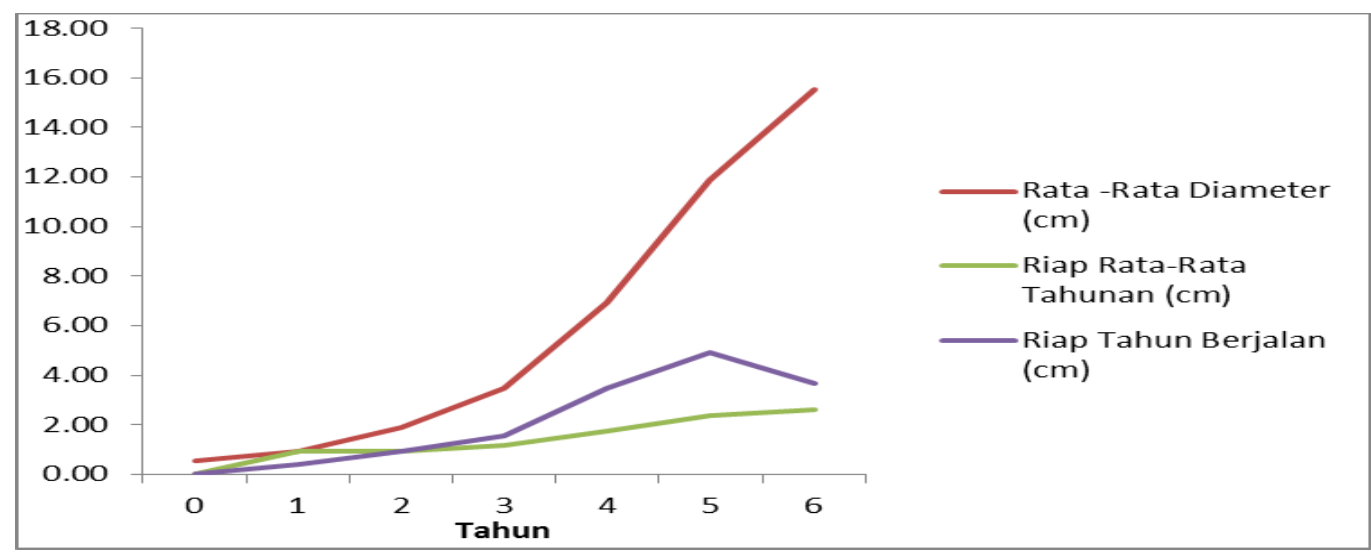

Gambar 4. Rata-Rata Diameter, Riap Rata-Rata Tahunan Dan Riap Tahun Berjalan Diameter Tanaman Titi

Gambar 4 menunjukkan bahwa riap tahun berjalan akan mengalami penurunan pada saat riap rata-rata tahunan masih mengalami peningkatan. Gambaran ini sesuai dengan kurva pertumbuhan pohon pertemuan antara riap rata-rata tahunan dan riap tahun berjalan akan menentukan daur teknis dari suatu jenis sesuai dengan pendapat Bettinger et al (2009) dalam Wahyudi (2013). Selain itu dengan 
mengetahui riap rata-rata tahunan dan riap tahun berjalan dapat juga menentukan rotasi atau daur maksimum dari suatu jenis(Aswandi, 2011). Dengan mengabaikan pertemuan yang terjadi pada tahun kedua maka dapat dipastikan berdasarkan grafik yang ada daur teknik dari jenis ini berada di atas umur 6 tahun.

Berdasarkan riap rata-rata tahunan dari tanaman Titi maka dapat diprediksi sesuai dengan sistem silvikultur untuk hutan tanah kering, jika jenis ini dapat ditebang untuk produksi kayu yaitu dengan diameter $\geq 40 \mathrm{~cm}$ maka pada umur 24,5

\section{KESIMPULAN}

Berdasarkan hasil dan pembahasan pada bab sebelumnya maka dapat disimpulkan sebagai berikut:

1. Pertumbuhan Tanaman Titi sejak penanaman hingga pada tahun keenam dipengaruhi oleh faktor lingkungan $\mathrm{pH}$ tanah dan kelembaban tanah.

2. Riap rata-rata tahunan dan riap tahun berjalan tinggi tanaman Titi sampai tahun keenam yaitu 0,99 meter/tahun dan 1,46 meter

\section{DAFTAR PUSTAKA}

Abdurachman, A. Saridan, I. Lanniari, 2009, Potensi dan Riap Diameter Jenis Aquilaria malaccensis LAMK di Hutan Alam Produksi Labanan, Kabupaten Berau, Kalimantan Timur, Jurnal Penelitian Hutan dan Konservasi Alam Volume VI No. 1 Tahun 2009 Halaman 1-11.

Adi, D. S; I. Wahyuni; L. Risanto, S. Rullianty, E. Hermiati, W. Dwianto, T. Watanbe, 2015, Central Kalimantan's Fast Growing Species : Suitable For Pulp and Paper, Indonesian Journal of Forestry Recerch Vol. 2 Nomor 1, April 2015, Halaman 21-29, tahun jenis ini dapat dipanen. Jika dibutuhkan untuk kebutuhan pulp dan kertas maka sebagai jenis lokal maka Titi dapat dipanen ketika sudah mencapai daur teknik, atau berdasarkan hasil penelitian berada di atas usia 6 tahun. Pendapat ini sesuai dengan apa yang dikemukakan oleh Haroen dkk (1997) dalam Soedomo dkk (2007) makin tua umur pohon maka semakin meningkat kadar $\alpha$ selulosa, zat ekstraktif dan lignin, sehingga dibutuhkan pohon dengan umur yang masih muda atau pohon yang sudah memasuki daur tekniknya.

3. Riap rata-rata tahunan dan riap tahun berjalan diameter tanaman Titi sampai tahun keenam adalah 1,62 cm/tahun dan $2,50 \mathrm{~cm}$

4. Sampai pada umur 6 tahun tanaman Titi pada Demplot sumber benih Desa Hatusua belum mencapai daur teknik. Untuk keperluan kayu pertukangan maka jenis ini dapat dipanen pada umur 24,5 tahun sedangkan untuk pulp dan kertas dapat dipanen setelah memasuki daur tekniknya.

ISSN : 2355-7079/E- ISSN : 2406-8195

Adman ,B, B. Hendrarto, D. P. Sasongko, 2012, Pemanfaatan Jenis Pohon Lokal Cepat Tumbuh Untuk Pemulihan Lahan Pascatambang Batubara (Studi Kasus di PT. Singlurus Pratama, Kalimantan Timur), Jurnal Ilmu Lingkungan Volume 10 Issue I Halaman 1925, ISSN 1829-8907.

Aswandi, 2011, Model Pertumbuhan Dan Hasil Hutan Tanaman Eucalyptus grandis Hill Ex Maiden Di Aek Nauli Simalungun Sumatra Utara, Widyariset, Vol. 14 No.2 :313-321 
de Kok, R, 2012, A Revision of The Genus Gmelina (Lamiaceae), Kew Bulletin Vol.67 : 293-329, ISSN : 0075-5974/EISSN : 1874-9334

Karamina, H. · W. Fikrinda · A.T. Murti, 2017, Kompleksitas pengaruh temperatur dan kelembaban tanah terhadap nilai $\mathrm{pH}$ tanah di perkebunan jambu biji varietas kristal (Psidium guajava 1.) Bumiaji, Kota Batu, Jurnal Kultivasi Vol. 16 (3) Desember 2017, Halaman 430-434

Kementerian Kehutanan Republik Indonesia, 2009, Peraturan Menteri Kehutanan No. P.11/MenhutII/2009, Berita Negara Republik Indonesia Tahun 2009 Nomor :24, Kementerian Hukum Dan Hak Azasi Manusia Republik Indonesia, Jakarta

Paembonan, S. A, 2014, Hutan Tanaman Dan Serapan Karbon, Masagena Press, Makassar

Sofyan, A, A.H. Lukman, Junaidah, Nasrun. S, 2013, Peningkatan Riap Pertumbuhan Tanaman Tembesu Melalui Beberapa Perlakuan Silvikultur, www.forda-mof.org, diakses tanggal 12 November 2019.

Sudomo, A, P.Permadi, E. Rachman, 2007, Kajian Kontrol Silvikultur Hutan Tanaman terhadap Kualitas Kayu Pulp, Info Teknis Volume 5 Nomor 2 Tahun 2007, Halaman 1-10, Balai Besar Penelitian Bioteknologi dan Pemuliaan Tanaman Hutan
Sutisna, U.T. Kalima dan Purnadjaja. 1998. Pedoman Pengenalan Pohon Hutan Di Indonesia. Disunting oleh Soetjipto, N. W. dan Soekotjo. Yayasan PROSEA Bogor dan Pusat Diklat Pegawai \& SDM Kehutanan. Bogor.

Tetelay, F. F, 2006, Studi Pengaruh Variasi HabitatTerhadap Pertumbuhan Gmelina moluccana (Blume) Backer Pada Beberapa Tempat Tumbuh Alaminya di Kota Ambon, Sekolah Pascasarjana Universitas Gadjah Mada, Yogyakarta (Tesis tidak dipublikasikan)

Wahyudi, 2013, Sistem Silvikultur di Indonesia Teori Dan Implementasi, Jurusan Kehutanan Fakultas Pertanian Universitas Palangkaraya, Palangkaraya. 